
Not for reproduction, distribution or commercial use.

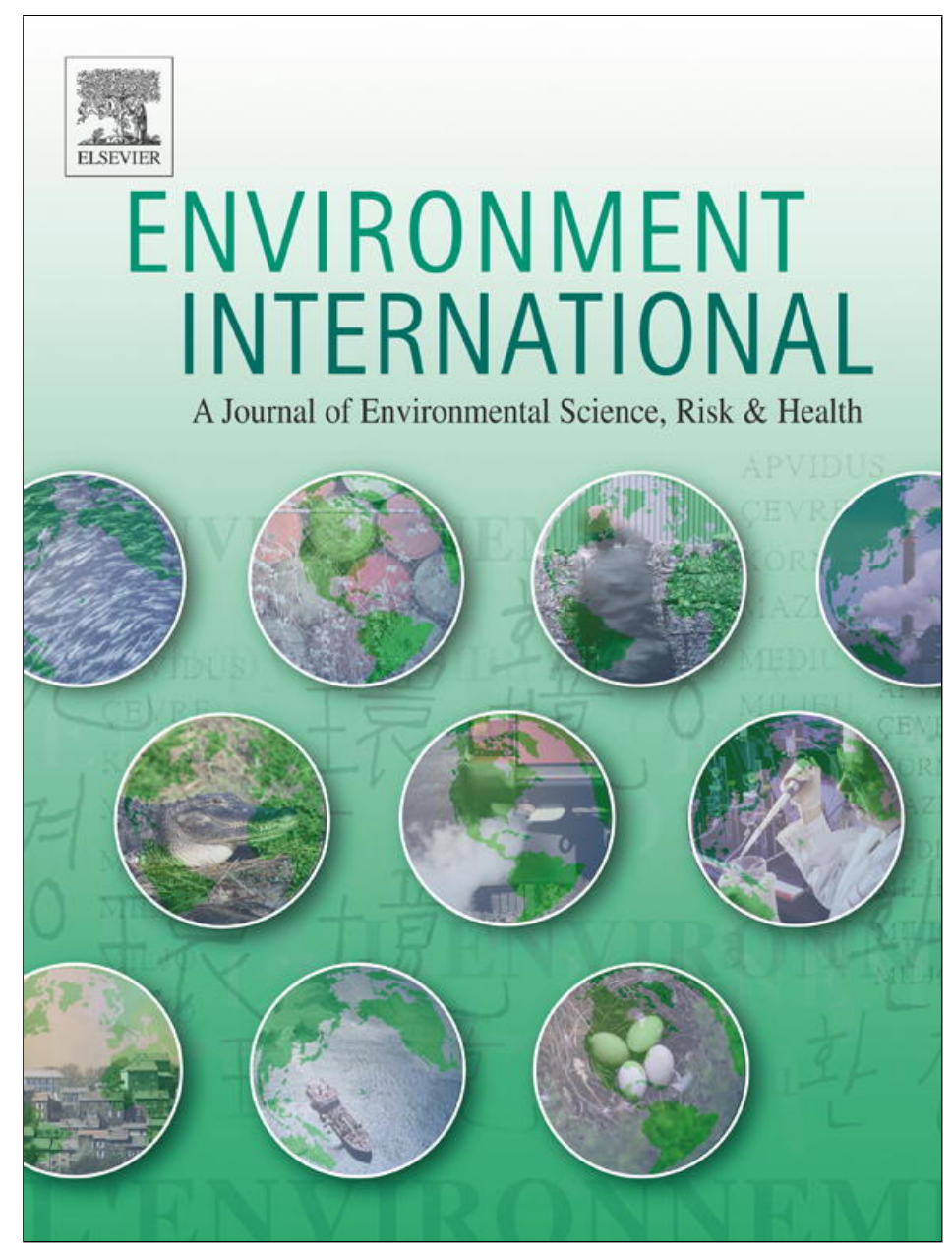

(This is a sample cover image for this issue. The actual cover is not yet available at this time.)

This article appeared in a journal published by Elsevier. The attached copy is furnished to the author for internal non-commercial research and education use, including for instruction at the authors institution and sharing with colleagues.

Other uses, including reproduction and distribution, or selling or licensing copies, or posting to personal, institutional or third party websites are prohibited.

In most cases authors are permitted to post their version of the article (e.g. in Word or Tex form) to their personal website or institutional repository. Authors requiring further information regarding Elsevier's archiving and manuscript policies are encouraged to visit: 


\title{
Evidence of DNA damage in humans inhabiting a volcanically active environment: A useful tool for biomonitoring
}

\author{
A.S. Rodrigues ${ }^{\text {a,b }}$, M.S.C. Arruda ${ }^{\text {b }}$, P.V. Garcia ${ }^{\text {b,c,* }}$ \\ a CVARG, Centro de Vulcanologia e Avaliação de Riscos Geológicos, Ponta Delgada, Portugal \\ b CIRN, Department of Biology, University of Azores, Ponta Delgada, Portugal \\ c CITA-A, Centro de Investigação e Tecnologias Agrárias dos Açores, Angra do Heroísmo, Portugal
}

\section{A R T I C L E I N F O}

\section{Article history:}

Received 6 June 2012

Accepted 17 August 2012

Available online $\mathrm{xxxx}$

\section{Keywords:}

Buccal exfoliated cells

Micronuclei

Genotoxic

Volcanism

\begin{abstract}
A B S T R A C T
The present study was designed to evaluate whether chronic exposure to a volcanically active environment might result in genotoxic and cytotoxic effects in human oral epithelial cells. A study group of 120 individuals inhabiting a volcanically active environment (exposed group; Furnas village) and a reference group of 122 individuals inhabiting a village without manifestations of volcanic activity (Santo António village) were examined in this study. Individuals from Furnas village inhabit a volcanically active environment marked by several degassing manifestations, including fumarolic fields, thermal and cold $\mathrm{CO}_{2}$ springs and soil diffuse degassing areas. For each individual, 1000 buccal epithelial cells were analyzed for the frequency of micronucleated cells (MNC) and the frequency of cells with other nuclear anomalies (ONA: pyknosis, karyolysis and karyorrhexis), by using the micronucleus assay. Information on life-style factors and an informed consent were obtained from each participant. The frequencies of MNC and of ONA per 1000 cells in the exposed group (4.3\% and $23.5 \%$, respectively) were significantly higher than in the reference group (1.7\% and $7.7 \%$, respectively). The risk of having a high frequency of MNC or ONA was 2.4 and 3.1 -fold higher in exposed individuals compared to reference group. The analyzed confounding factors (age, gender, smoking status, alcohol consumption, and mouthwash use) did not show any significant association with the frequency of MNC or ONA. The higher risk of DNA damage in individuals inhabiting a volcanically active environment is for the first time clearly highlighted with this biomonitoring study. Given that MNC in oral epithelia are recognized as a predictive biomarker of cancer risk within a population of healthy subjects, these findings could contribute to explain the high incidence rates of lip, oral cavity and pharynx cancers previously referred for Furnas village inhabitants.
\end{abstract}

(c) 2012 Elsevier Ltd. All rights reserved.

\section{Introduction}

It is estimated that a lot more than $10 \%$ of the worldwide population lives within potential exposure range of some active or historically active volcano, either erupting or in a post-eruption phase. Despite all the hazards associated with the activity of volcanoes, the richness of the soils in nutrients increasingly attracts people to live on or in the vicinity of active volcanoes, as it happens, in the Azores and Hawaii archipelagos, oceanic islands of hotspot volcanism (Amaral and Rodrigues, 2011; Hansell et al., 2006). Present-day volcanic activity in the Azores archipelago is marked by several hydrothermal manifestations consisting of active fumarolic fields, thermal and cold $\mathrm{CO}_{2}$ springs and soil diffuse degassing areas (Baxter et al.,

\footnotetext{
Abbreviations: MNC, micronucleated cells; ONA, cells with other nuclear anomalies. * Corresponding author at: Departamento de Biologia, Universidade dos Açores, Rua da Mãe de Deus, Apartado 1422, 9501-801 Ponta Delgada, Açores, Portugal. Tel.: + 351 296650460; fax: + 351296650100

E-mail addresses: rodrigues@uac.pt (A.S. Rodrigues), arrumonica@gmail.com (M.S.C. Arruda), patriciag@uac.pt (P.V. Garcia).
}

1999; Viveiros et al., 2008, 2009). According to these authors one of the major soil diffuse degassing areas of the archipelago extends below Furnas village. Soil diffuse degassing areas are potentially one of the main hazardous zones to humans, as gases and aerosols are continuously released (not only during the eruptive unrest, but also in quiescent phases of the volcanoes) and can rise below edifices without being noticed by the population (Viveiros et al., 2009). Among such gases, the following are highlighted for Furnas soil diffuse degassing areas and fumarolic discharges: carbon dioxide $\left(\mathrm{CO}_{2}\right)$, hydrogen sulfide $\left(\mathrm{H}_{2} \mathrm{~S}\right)$, sulfur dioxide $\left(\mathrm{SO}_{2}\right)$, hydrogen chloride $(\mathrm{HCl})$, hydrogen fluoride $(\mathrm{HF})$, and, the radioactive gas radon (Rn) (Ferreira et al., 2005; Viveiros et al., 2009). Carbon dioxide is the most important material released by soil degassing in Furnas (hydrothermal soil $\mathrm{CO}_{2}$ emissions in Furnas volcano are estimated to be $\sim 968 \mathrm{t} \mathrm{d}^{-1}$ ), and if present at high concentrations can become particularly dangerous for public health, since it prevents oxygen respiration (Viveiros et al., 2009, 2010), with asphyxia occurring at a concentration around 10 vol.\% (Durand, 2006). Hydrogen sulfide is a colorless, flammable and noxious asphyxiant gas, having the distinctive odor of rotten eggs recognizable at concentration up to 
$30 \mathrm{ppm}$; at low concentrations (up to $50 \mathrm{ppm}$ ) it can cause irritation of the conjunctivae and depressive states, whereas when at high concentrations it can irritate the upper respiratory tract, causing pharyngitis and bronchitis, and in the lungs, especially as a result of long-term exposures, it promotes pulmonary edema (Amaral and Rodrigues, 2011; Durand, 2006; Durand and Wilson, 2006); a possible association between this gas and cancer was suggested by Attene-Ramos et al. (2006). Sulfur dioxide is a colorless and pungently odorous irritant gas, capable of causing acute and chronic diseases, particularly of the respiratory system (Amaral and Rodrigues, 2011; Iwasawa et al., 2009). Hydrogen chloride can cause damage to the respiratory tract and it can lead to erosion of teeth and skin rashes, while long term exposure to hydrogen fluoride can cause dental fluorosis in children and skeletal fluorosis in adults. Though $\mathrm{HCl}$ and $\mathrm{HF}$ have not been classified for carcinogenic effects, some researchers suspect that long term exposure to these gases may play a role in the incidence of some cancers due to their very aggressive and acid nature, which can promote oxidative stress, especially in cells of the respiratory system (Amaral and Rodrigues, 2011). Radon is a radioactive gas, odorless and colorless that is known to easily accumulate indoor, mainly in basements and other lower floors, being its most important isotope ${ }^{222} \mathrm{Rn}$. As a gas, radon is relatively harmless, but in contrast, radon decay results in solid particles that readily settle within the airways; these decay products emit alpha radiation that is capable of causing severe DNA damage by a direct hit on the DNA (Sethi et al., 2012). Although the initial evidence supporting the association of radon and lung cancer came from studies involving mine workers (IARC, 1988), research in recent years has focused on indoor radon exposure and its risk to the general population (Brooks et al. 1997; Field et al., 2001; Jostes, 1996; Turner et al., 2011). The evidence available to date suggests that radon may be responsible for $3 \%$ to $15 \%$ of the lung cancer, making radon the second leading cause of lung cancer after tobacco smoke (Sethi et al., 2012). Associated with volcanic gases and aerosols, quiescent volcanoes also release heavy metals like arsenic (As), cadmium (Cd), mercury ( $\mathrm{Hg})$, aluminum $(\mathrm{Al})$, rubidium $(\mathrm{Rb})$, lead $(\mathrm{Pb})$, magnesium $(\mathrm{Mg})$, copper $(\mathrm{Cu})$ and zinc (Zn) (Durand et al., 2004). Some of these heavy metals are well known to induce toxic effects when people are exposed to them, through either inhalation or ingestion (Amaral and Rodrigues, 2011). For example, $\mathrm{Pb}$ is considered to be neurotoxic (Reddy et al., 2007) and Cd is well recognized as carcinogenic (Waalkes, 2003) to humans, while $\mathrm{Rb}$ has been found in high levels in malignant and benign thyroid nodules (Zaichick et al, 1995).

Human biomonitoring may be done using various cytogenetic tests that evaluate genotoxic effects by detecting DNA damage, such as sister chromatid exchanges and micronuclei (Hagmar et al., 1998; Holland et al., 2008). Micronuclei in exfoliated buccal epithelial cells emerge during mitosis of the basal layers of the epithelium as extra chromosomal DNA particles, when chromosome fragments or whole chromosomes lag behind and fail to be included in the main nuclei of the daughter cells, as a result of a clastogenic or aneugenic events (Holland et al., 2008; Tolbert et al., 1992). Micronuclei in epithelial cells reflect genotoxic events occurring in the dividing basal cell layer 1-3 weeks earlier of the putative target organ (Stich et al., 1983; Tolbert et al., 1991), which allows for cytogenetic surveillance of groups at high risk of developing organ-specific cancer (e.g., upper aerodigestive tract) or oral premalignant lesions (Bloching et al., 2000; Mahimkar et al., 2010; Saran et al., 2008). Chromosomal damage in epithelial cells also leads to nuclear anomalies other than micronuclei, such as karyorrhexis, karyolysis, pyknosis, condensed chromatin, broken eggs and binucleated cells (Holland et al., 2008; Thomas et al., 2009). Karryohexis, karyolysis and pyknosis are associated with both cytotoxicity (necrosis and keratinization) and genotoxicity (apoptosis) accompanying the early stages of apoptosis (Tolbert et al., 1991, 1992), and thus are also considered effective biomarkers for populations exposed to mutagenic and carcinogenic agents (Salama et al., 1999). The micronucleus assay with exfoliated cells is emerging as a preferential method to measure that type of damage (Holland et al., 2008), because it is considered a sensitive and non-invasive method for monitoring DNA damage in human populations (Bloching et al., 2000; Garcia et al., 2012; Majer et al., 2001). Recently, such approaches have been frequently used in biomonitoring studies of occupational and environmental exposure to carcinogenic substances (e.g., Garcia et al., 2012; Hallare et al., 2009; Martínez-Valenzuela et al., 2009; Martins et al., 2009; Rozgaj et al., 2009), but to our knowledge no study has been done to assess the risk of DNA damage in individuals inhabiting volcanically active environments. Since previous studies in Furnas have showed that: (i) soil invertebrates and mice present high levels of trace metals, such as Cd and Zn (A. Amaral et al., 2006; Amaral et al., 2007); and (ii) humans present high incidence of chronic bronchitis and some cancer types, especially of lip, oral cavity and pharynx, which may be related to volcanic emissions (Amaral and Rodrigues, 2007; A.F.S. Amaral et al., 2006), the present study was designed to evaluate whether chronic exposure to a volcanically active environment might result in DNA damage in human oral epithelial cells.

\section{Materials and methods}

\subsection{Study population}

The Azores archipelago comprises nine volcanic islands, located between $36^{\circ} 45^{\prime}-39^{\circ} 43^{\prime} \mathrm{N}$ and $24^{\circ} 45^{\prime}-31^{\circ} 17^{\prime} \mathrm{W}$, where the Eurasian, American and African lithospheric plates meet (Searle, 1980). On account of this complex tectonic setting, seismic and volcanic activities are frequent in the archipelago (Searle, 1980; Viveiros et al., 2008). Within the island of São Miguel (Azores, Portugal) there are villages located at volcanically active environments, like Furnas, and others without historical records for active volcanism, like $\mathrm{St}^{\mathrm{o}}$ António. The group exposed to the volcanically active environment consisted of 120 inhabitants (90 women and 30 men) from Furnas village (Table 1). This village is located inside the Furnas volcano caldera, where present-day volcanic activity is marked by several hydrothermal manifestations consisting of active fumarolic fields and hydrothermal vents (Booth et al., 1978; Cruz, 2003) and soil diffuse

\section{Table 1}

Age, gender, main lifestyle habits and residence time of the groups exposed (Furnas vil-

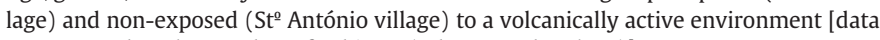
are reported as the number of subjects (\% between brackets)].

\begin{tabular}{|c|c|c|}
\hline & Furnas inhabitants & $\mathrm{St}^{\circ}$ António inhabitants \\
\hline Subjects $(\mathrm{N})$ & 120 & 122 \\
\hline Mean age ${ }^{a}$ & $45.0 \pm 18.4$ & $45.1 \pm 16.1$ \\
\hline \multicolumn{3}{|l|}{ Age } \\
\hline$\leq 45$ years $^{\mathrm{b}}$ & $65(54.2 \%)$ & $56(45.9 \%)$ \\
\hline$>45$ years $^{\mathrm{b}}$ & $55(45.8 \%)$ & $66(54.1 \%)$ \\
\hline \multicolumn{3}{|l|}{ Gender } \\
\hline Female & 90 & 89 \\
\hline Male & 30 & 33 \\
\hline \multicolumn{3}{|l|}{ Smoking status } \\
\hline Regular smoker & $29(24.2 \%)$ & $7(5.7 \%)$ \\
\hline Non-smoker & $91(75.8 \%)$ & 115 (94.3\%) \\
\hline Cigarettes/day ${ }^{\mathrm{c}}$ & $19.2 \pm 13.1$ & $16.7 \pm 14.4$ \\
\hline \multicolumn{3}{|c|}{ Alcohol consumption } \\
\hline Yes & $36(30.0 \%)$ & $35(28.7 \%)$ \\
\hline No & $84(70.0 \%)$ & $87(71.3 \%)$ \\
\hline \multicolumn{3}{|c|}{ Use of mouthwash elixir } \\
\hline Yes & $76(63.3 \%)$ & $65(53.3 \%)$ \\
\hline No & $44(36.7 \%)$ & $57(46.7 \%)$ \\
\hline Residence time $^{a}$ & $38.4 \pm 20.9$ & $41.3 \pm 18.5$ \\
\hline
\end{tabular}

${ }^{a}$ Age and residence time are expressed in years and reported as the group mean \pm standard deviation.

${ }^{b}$ Cut-off defined according to the mean value (i.e. 45.97 years) of the observed age distribution in the whole population.

c The number of cigarettes smoked per day is reported as the group mean \pm standard deviation. 
degassing areas with the always present "rotten egg" odor (Viveiros et al., 2008, 2009). Furnas village has 1541 inhabitants (Serviço Regional de Estatística dos Açores, 2003) that are continuously exposed to gases of volcanic origin, particularly those from soil degassing. According to Viveiros et al. $(2008,2009)$ one of the major soil diffuse degassing areas in the island of São Miguel extends below this village, with some houses located in areas where the risk of asphyxia is high due to significant indoor soil $\mathrm{CO}_{2}$ flux increases. The non-exposed group included 122 individuals ( 89 women and 33 men), inhabitants of $\mathrm{St}^{\mathbf{0}}$ António village (Table 1$)$. This village, with 2004 inhabitants (Serviço Regional de Estatística dos Açores, 2003), is located in the north side of São Miguel Island in an area without manifestations of active volcanism. Table 1 summarizes the demographic characteristics and main lifestyle habits of studied populations. Both populations are similar in access to medical care, socioeconomic status and types of home construction. All individuals gave written informed consent to participate in this study. A standard questionnaire was used to interview each person about their age, gender, residence time, nature of occupation, smoking habits (consumption of smoking and/or smokeless tobacco), alcohol consumption, frequent use of mouthwash, performance of X-rays in the previous week, and general health status. Only individuals that resided for more than five years in each locality were considered for this study.

\subsection{Micronuclei and other nuclear anomalies analysis in buccal epitheli- al cells}

Exfoliated buccal epithelial cells were obtained from inside of both cheeks by gently scrubbing the mucosa with a sterile cytobrush and smeared onto pre-cleaned glass slides. After air-drying, cells were fixed in methanol for $20 \mathrm{~min}$ at $0{ }^{\circ} \mathrm{C}$, and the Feulgen method [modified from Tolbert et al. $(1991,1992)]$ was applied. Feulgen-stained slides were evaluated under a light microscope with a 1000-fold magnification, using immersion oil. For each individual, 1000 epithelial cells were analyzed for the frequency of cells with one or more micronuclei (MNC) and other nuclear anomalies (ONA). The following other nuclear anomalies were considered: karyolysis (nucleus depleted of DNA, in which a Feulgen-negative ghost-like image of the nucleus remains), pyknosis (nucleus is one- to two-thirds of a nucleus in normal differentiated cells), and karyorrhexis (nuclear disintegration associated with loss of nuclear membrane integrity). The scoring of MNC or ONA was done according to the criteria set by Thomas et al. (2009).

\subsection{Statistical analysis}

The Mann-Whitney $U$ test was used to compare the frequencies of MNC and of ONA between individuals inhabiting a volcanically active environment and individuals inhabiting a village without manifestations of active volcanism (exposed and reference groups, respectively). To estimate the association between chronic exposure to a volcanically active environment and frequency of MNC, relative risks (RRs) and 95\% confidence intervals (95\% CIs) were calculated using negative binomial regression models (Ceppi et al., 2010, 2011 ), adjusting for age ( $\leq 45$ vs. $>45$ years), gender (male vs. female), smoking status (non-smoker vs. regular smoker), alcohol consumption (no vs. yes), and mouthwash use (no vs. yes). The same approach was applied for the ONA. All statistical analyses were performed using SPSS 15.0 for Windows (SPSS Inc., 2006), and the level of statistical significance was set at $P \leq 0.05$.

\section{Results}

The two study groups were comparable in terms of age, gender, smoking status, alcohol drinking, and mouthwash use (Table 1).
Among regular smokers, none used smokeless tobacco. None of the participants had an X-ray in the week previous to the collection of exfoliated buccal epithelial cells.

\subsection{MNC and ONA frequencies}

The frequency (mean \pm S.E.) of MNC per 1000 cells in the group exposed to the volcanically active environment was significantly higher than in the non-exposed group ( $4.3 \pm 0.2 \%$ ov $1.7 \pm 0.1 \%$, respectively; $P<0.001$; Fig. 1 A). Similarly, the frequency (mean \pm S.E.) of ONA per 1000 cells in the exposed group was also significantly higher in comparison to the non-exposed group ( $23.5 \pm 1.7 \%$ 。 vs $7.7 \pm 0.3 \%$, respectively; $P<0.001$; Fig. $1 \mathrm{~B}$ ).

\subsection{Association between exposure to a volcanically active environment and MNC or ONA frequencies}

Exposure to the volcanically active environment was a significant predictor of the frequency of MNC and of the frequency of ONA, both in the univariate and multivariate analyses. After adjustment for age, gender, smoking status, alcohol consumption, and mouthwash use, a higher MNC frequency was found associated with exposure to the volcanically active environment $(\mathrm{RR}=2.4 ; 95 \% \mathrm{CI}, 1.8-3.3 ; P<0.001)$ (Table 2). A higher ONA frequency was also found associated with exposure to the volcanically active environment $(\mathrm{RR}=3.1 ; 95 \% \mathrm{CI}, 2.3-4.1$; $P<0.001$ ) (Table 3), after adjustment for covariates.

\section{Discussion}

Several cytogenetic endpoints have been extensively used for biomonitorization of human exposure to carcinogenic substances (Ceppi et al., 2010; Knudsen and Hansen, 2007), being the increase in MNC considered predictive of elevated cancer risk (Bloching et al., 2000; Bonassi et al., 2007; Mahimkar et al., 2010; Saran et al., 2008). According to Holland et al. (2008), buccal epithelial cells represent a recognized target site for early genotoxic events induced by carcinogenic substances that enter the body via inhalation or ingestion. In volcanically active environments, humans are exposed to several volcanogenic hazardous elements mainly via inhalation. Among such hazardous elements, Rn and Cd are well recognized as carcinogenic to humans (Brooks et al., 1997; Field et al., 2001; Jostes, 1996; Waalkes, 2003). Turner et al. (2011), in a large-scale cohort study to analyze the association between residential radon and lung cancer mortality in North America, observed a 15\% increase in lung cancer mortality for each $100 \mathrm{~Bq} \mathrm{~m}^{-3}$ increase in radon concentration and, participants with mean radon concentrations above the U.S. Environmental Protection Agency guideline value $\left(148 \mathrm{~Bq} \mathrm{~m}^{-3}\right)$ experienced a $34 \%$ increase in risk for lung cancer mortality relative to those below the guideline value. According to Silva et al. (2007) the values for ${ }^{222} \mathrm{Rn}$ in the main soil diffuse degassing area in Furnas caldera are found to be mostly associated to $\mathrm{CO}_{2}$ anomalous areas and high concentrations of this radioactive gas in inhabited houses were recorded within the Furnas caldera, where Rn concentrations were in average $6702 \mathrm{~Bq} \mathrm{~m}^{-3}$, from a total of 175 measured points. In some cases the measured values reached $110 \mathrm{kBq} \mathrm{m}^{-3}$, which is many times more than the reference level $\left(200-400 \mathrm{~Bq} \mathrm{~m}^{-3}\right)$ for indoor air in most countries; such high concentrations of indoor Rn make Furnas' inhabitants likely to be at a high risk of developing cancers, particularly of the respiratory tract. Therefore, it is highly possible that the higher risk of DNA damage in the buccal epithelia of Furnas' inhabitants is mainly associated with exposure to the high concentrations of residential $\mathrm{Rn}$. In a recent review that analyzes the increased incidence of thyroid cancer in volcanic areas around the world, Duntas and Doumas (2009) refer the presence of Cd and radioactivity as factors potentially involved in thyroid tumorigenesis in volcanic regions. In Furnas village, $\mathrm{Cd}, \mathrm{Cu}, \mathrm{Pb}, \mathrm{Rb}$ and $\mathrm{Zn}$ are usually present in volcanic 

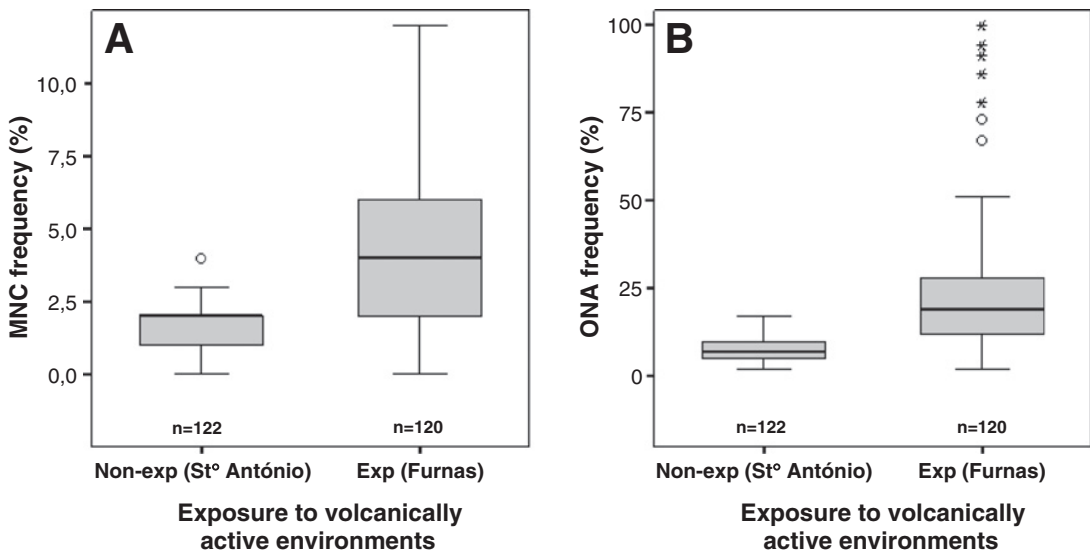

Fig. 1. Box plot diagrams showing frequency distribution of cells with micronuclei (A) and of cells with other nuclear anomalies (B) per 1000 cells in the groups chronically exposed (Furnas village inhabitants) and non-exposed ( $\mathrm{St}{ }^{\circ}$ António village inhabitants) to an environment with active volcanism; line within the box, median; thin vertical lines represent minimum and maximum values; extreme values $\left(^{*}\right)$ and outliers $(O)$.

emissions, and there seems to be evidence for a high bioavailability of these elements as shown by their concentrations in the scalp hair of its inhabitants (Amaral et al., 2008). Though according to the International Agency for Research on Cancer $\mathrm{SO}_{2}$ is not classifiable as to its carcinogenicity (IARC, 1992), some studies have associated this gas with DNA damage. Meng et al. $(2002,2005)$ have reported that inhaled $\mathrm{SO}_{2}$ damaged the DNA of multiple organs of mice (in addition to the lung) and suggested that the damages could result in mutation, cancer, and other diseases related to DNA damage. Some studies have shown that occupational exposure to $\mathrm{SO}_{2}$ increases DNA damage in peripheral blood lymphocytes of workers (Yadav and Kaushik, 1996), and epidemiological evidence has linked $\mathrm{SO}_{2}$ exposure with lung cancer (Lee et al., 2002; Pope et al., 1995). In addition, and since the atmosphere in Furnas is too wet, the Furnas volcanic environment promotes the conversion of $\mathrm{SO}_{2}$ to $\mathrm{H}_{2} \mathrm{SO}_{4}$, a gas that according to the International Agency for Research on Cancer (IARC 1992) is considered to be carcinogenic to humans. Other volcanogenic elements, like $\mathrm{Rb}$ are suspected to be associated with malignant lesions of the thyroid nodules (Zaichick et al., 1995), while $\mathrm{H}_{2} \mathrm{~S}$ was shown to be associated to colorectal cancer
(Attene-Ramos et al., 2006). Summing up, when living in volcanically active environments, like Furnas village, humans are exposed to several hazardous elements that may be associated to the development of several cardiovascular, nervous and respiratory system diseases, and inclusive of cancers; however, to our knowledge no study has been done to assess the risk of DNA damage in individuals inhabiting volcanically active environments. The present study reports, for the first time, an association between exposure to the volcanically active environment and the frequency of MNC, with a 2.4-fold increase in the risk for Furnas' inhabitants. The frequency of MNC in the reference group (inhabitants of Santo António village) was lower than 2 per 1000 cells, which is within the normal range for human oral epithelia (0.5-2.5 MNC/1000) as reported by Ceppi et al. (2010) and Holland et al. (2008). Similarly, a significant association between exposure to the volcanically active environment and the frequency of ONA (karyorrhexis, karyolysis, and pyknosis) was observed, with a 3-fold increase in the risk for Furnas' inhabitants. Our results support the hypothesis raised by A.F.S. Amaral et al. (2006) in a 10-yr follow-up study to analyze the cancer incidence in humans chronically exposed to a volcanically active environment: these authors have

Table 2

Association between characteristics of study participants and exposure to an environment with active volcanism, as well as the frequency of micronucleated cells of the buccal epithelia.

\begin{tabular}{|c|c|c|c|c|c|c|c|}
\hline & \multirow[t]{2}{*}{$\mathrm{N}(\%)$} & \multicolumn{2}{|c|}{ Micronucleated cells ${ }^{\mathrm{a}}$} & \multicolumn{2}{|l|}{ Univariate analysis } & \multicolumn{2}{|c|}{ Multivariate analysis ${ }^{c}$} \\
\hline & & Mean & Maximum & $\mathrm{RR}^{\mathrm{b}}(95 \% \mathrm{CI})$ & $P$-value & $\mathrm{RR}^{\mathrm{b}}(95 \% \mathrm{CI})$ & $P$-value \\
\hline \multicolumn{8}{|l|}{ Age } \\
\hline$\leq 45$ & $119(49)$ & 3.07 & 11 & 1.00 & & & \\
\hline$>45$ & $123(51)$ & 2.91 & 12 & $0.95(0.71-1.27)$ & 0.724 & & \\
\hline \multicolumn{8}{|l|}{ Gender } \\
\hline Male & $63(26)$ & 2.94 & 9 & 1.00 & & & \\
\hline Female & $179(74)$ & 3.01 & 12 & $1.02(0.73-1.43)$ & 0.891 & & \\
\hline \multicolumn{8}{|l|}{ Smoking status } \\
\hline Nonsmoker & $206(85)$ & 2.84 & 12 & 1.00 & & & \\
\hline Regular smoker & $36(15)$ & 3.81 & 9 & $1.34(0.90-1.99)$ & 0.154 & & \\
\hline \multicolumn{8}{|c|}{ Alcohol consumption } \\
\hline No & $171(71)$ & 3.09 & 12 & 1.00 & & & \\
\hline Yes & $71(29)$ & 2.75 & 9 & $0.89(0.65-1.23)$ & 0.476 & & \\
\hline \multicolumn{8}{|l|}{ Mouthwash use } \\
\hline No & $101(42)$ & 2.78 & 12 & 1.00 & & & \\
\hline Yes & $141(58)$ & 3.13 & 10 & $1.23(0.84-1.52)$ & 0.430 & & \\
\hline \multicolumn{8}{|c|}{ Exposure to active volcanism } \\
\hline No & $122(50)$ & 1.74 & 4 & 1.00 & & 1.00 & \\
\hline Yes & $120(50)$ & 4.26 & 12 & $2.45(1.82-3.30)$ & $<0.001$ & $2.41(1.77-3.30)$ & $<0.001$ \\
\hline
\end{tabular}

a Micronucleated cells per 1000 cells.

b RR, relative risk; $95 \% \mathrm{CI}, 95 \%$ confidence interval.

c Adjusted for age, gender, smoking status, alcohol consumption, and mouthwash use. 
Table 3

Association between characteristics of study participants and exposure to an environment with active volcanism, as well as the frequency of cells with other nuclear anomalies (karyorrhexis, karyolysis and pyknosis) of the buccal epithelia.

\begin{tabular}{|c|c|c|c|c|c|c|c|}
\hline & \multirow[t]{2}{*}{$\mathrm{N}(\%)$} & \multicolumn{2}{|c|}{$\begin{array}{l}\text { Cells with other nuclear } \\
\text { anomalies }^{\mathrm{a}}\end{array}$} & \multicolumn{2}{|c|}{ Univariate analysis } & \multicolumn{2}{|c|}{ Multivariate analysis ${ }^{c}$} \\
\hline & & Mean & Maximum & $\mathrm{RR}^{\mathrm{b}}(95 \% \mathrm{CI})$ & $P$-value & $\mathrm{RR}^{\mathrm{b}}(95 \% \mathrm{CI})$ & $P$-value \\
\hline \multicolumn{8}{|l|}{ Age } \\
\hline$\leq 45$ & $119(49)$ & 14.75 & 94 & 1.00 & & & \\
\hline$>45$ & $123(51)$ & 16.31 & 100 & $1.11(0.85-1.43)$ & 0.448 & & \\
\hline \multicolumn{8}{|l|}{ Gender } \\
\hline Male & $63(26)$ & 14.71 & 78 & 1.00 & & & \\
\hline Female & $179(74)$ & 15.83 & 100 & $1.08(0.80-1.45)$ & 0.628 & & \\
\hline \multicolumn{8}{|l|}{ Smoking status } \\
\hline Nonsmoker & $206(85)$ & 14.97 & 100 & 1.00 & & & \\
\hline Regular smoker & $36(15)$ & 18.81 & 67 & $1.26(0.87-1.81)$ & 0.219 & & \\
\hline \multicolumn{8}{|c|}{ Alcohol consumption } \\
\hline No & $171(71)$ & 16.55 & 100 & 1.00 & & & \\
\hline Yes & $71(29)$ & 13.11 & 73 & $0.79(0.59-1.06)$ & 0.111 & & \\
\hline Mouthwash use & & 1 & & & & & \\
\hline No & $101(42)$ & 14.61 & 86 & 1.00 & & & \\
\hline Yes & $141(58)$ & 16.21 & 100 & $1.01(0.85-1.44)$ & 0.442 & & \\
\hline \multicolumn{8}{|l|}{ Exposure to VOCs } \\
\hline No & $122(50)$ & 7.67 & 17 & 1.00 & & 1.00 & \\
\hline Yes & $120(50)$ & 23.54 & 100 & $3.07(2.36-3.99)$ & $<0.001$ & $3.06(2.32-4.03)$ & $<0.001$ \\
\hline
\end{tabular}

a Micronucleated cells per 1000 cells.

b RR, relative risk; $95 \% \mathrm{CI}, 95 \%$ confidence interval.

c Adjusted for age, gender, smoking status, alcohol consumption, and mouthwash use.

suggested that the much higher rates of lip, oral cavity and pharynx cancers and breast cancer in Furnas inhabitants could be partially explained by the chronic exposure to environmental factors resulting from volcanic activity, such as, hazardous gases, trace metals and radon.

Among the lifestyle and host confounding factors, smoking status, alcohol consumption, use of mouthwash, sex, age and gender have been associated with DNA damage in the literature, although many studies are contradictory or inconclusive in what concerns the establishment of statistically significant effects (Holland et al., 2008). However, among such factors, tobacco and alcohol consumption are usually considered to be associated to genetic damage (Holland et al., 2008). In the present study, none of the analyzed lifestyle and host confounding factors was significantly associated to the frequency of MNC or ONA. Though tobacco is known to contain various genotoxic chemicals (Pappas et al., 2006; Speit et al., 2003), several authors have also found that the occurrence of MNC or ONA was not significantly associated to smoking status in individuals exposed to other potentially carcinogenic substances, such as fuel derivatives (Garcia et al., 2012; Hallare et al., 2009; Martins et al., 2009) or pesticides (Martínez-Valenzuela et al., 2009; Rozgaj et al., 2009). Alcohol is also described as a genotoxic substance (Maluf and Erdtmann, 2000), but in this study, as well as in others (Garcia et al., 2012; Hallare et al., 2009; Martínez-Valenzuela et al., 2009) its consumption was not significantly associated with the increase in the frequency of MNC or ONA in the buccal epithelia.

In summary, our results show that there is a significant association between chronic exposure to volcanically active environments and the occurrence of DNA damage in human buccal epithelial cells of Furnas inhabitants, revealing that non-eruptive active volcanism is a risk factor of carcinogenesis. Therefore, biomonitoring for DNA damage (particularly micronuclei) is recommended for inhabitants of localities with active volcanism, such as Furnas' village. Moreover, in Furnas village the indoor gas hazard increases during extreme weather conditions, since inhabitants tend to close the doors and windows of their houses under such circumstances (Viveiros et al., 2009). Since our results evidence the carcinogenic potential of volcanogenic emissions, at least several mitigation measures should be taken into consideration, such as the restriction of building in certain localities and, the development and introduction of some construction techniques, like the installation of natural/forced ventilation systems and the use of an impermeable membrane in buildings located in degassing areas.

\section{Conflict of interest}

The authors declare that there are no conflicts of interest.

\section{Acknowledgments}

The authors thank all the participants in the study for their accessible cooperation, Ricardo Camarinho for technical assistance and André Amaral (CNIO) for the helpful comments and guidance on the statistical analysis. This work was financially supported by the project M2.1.2/I/008/2011 of the Azorean Government and by the Master's Program in Biomedical Sciences of the University of the Azores.

\section{References}

Amaral AFS, Rodrigues AS, Chronic exposure to volcanic environments and chronic bronchitis incidence in the Azores, Portugal. Environ Res 2007;103:419-23.

Amaral AFS, Rodrigues AS. Volcanogenic contaminants: chronic exposure. In: Nriagu J, editor. Encyclopedia of environmental health. New York: Elsevier BV; 2011. p. 681-9.

Amaral AFS, Rodrigues V, Oliveira J, Pinto C, Carneiro V, Sanbento R, et al. Chronic exposure to volcanic environments and cancer incidence in the Azores, Portugal. Sci Total Environ 2006a;367:123-8

Amaral A, Soto M, Cunha RMPTT, Marigómez I, Rodrigues AS. Bioavailability and cellular effects of metals on Lumbricus terrestris inhabiting volcanic soils. Environ Pollut 2006b;142:103-8.

Amaral AF, Cabral C, Guedes C, Rodrigues AS. Apoptosis, metallothionein, and bioavailable metals in domestic mice (Mus musculus L.) from a human-inhabited volcanic area. Ecotoxicology 2007; 16:475-82.

Amaral AFS, Arruda M, Cabral S, Rodrigues AS. Essential and non-essential trace metals in scalp hair of men chronically exposed to volcanogenic metals in the Azores, Portugal. Environ Int 2008;34:1104-8.

Attene-Ramos MS, Wagner ED, Plewa MJ Michael J, Rex Gaskins H. Evidence that hydrogen sulfide is a genotoxic agent. Mol Cancer Res 2006;4:9-14.

Baxter PJ, Baubron JC, Coutinho R. Health hazards and disaster potential of ground gas emissions at Furnas volcano, São Miguel, Azores. J Volcanol Geotherm Res 1999;92: 95-106.

Bloching M, Hofmann A, Lautenschalager CH, Berghaus A, Grummt T. Exfoliative cytology of normal buccal mucosa to predict the relative risk of cancer in the upper aerodigestive tract using the MN-assay. Oral Oncol 2000;36:550-5.

Bonassi S, Znaor A, Ceppi M, Lando C, Chang WP, Holland N, et al. An increased micronucleus frequency in peripheral blood lymphocytes predicts the risk of cancer in humans. Carcinogenesis 2007;28:625-31. 
Booth B, Croasdale R, Walker GPL. A quantitative study of five thousand years of volcanism on São Miguel, Azores. Philos Trans R Soc Lond A 1978;288:271-319.

Brooks AL, Bao S, Harwood PW, Wood BH, Chrisler WB, Khan MA, et al. Induction of micronuclei in respiratory tract following radon inhalation. Int J Radiat Biol 1997;72:485-95.

Ceppi M, Biasotti B, Fenech M, Bonassi S. Human population studies with the exfoliated buccal micronucleus assay: statistical and epidemiological issues. Mutat Res 2010;705:11-9.

Ceppi M, Gallo F, Bonassi S. Study design and statistical analysis of data in human population studies with the micronucleus assay. Mutagenesis 2011;26:247-52.

Cruz JV. Groundwater and volcanoes: examples from the Azores archipelago. Environ Geol 2003;44:343-55

Duntas LH, Doumas C. The 'rings of fire' and thyroid cancer. Hormones 2009;8:249-53.

Durand M. Indoor air pollution caused by geothermal gases. Build Environ 2006;41: 1607-10.

Durand M, Wilson JG. Spatial analysis of respiratory disease on an urbanized geothermal field. Environ Res 2006;101:238-45.

Durand M, Florkowski C, George P, Walmsley T, Weinstein P, Cole J. Elevated trace element output in urine following acute volcanic gas exposure. J Volcanol Geotherm Res 2004:134:139-48

Ferreira T, Gaspar JL, Fátima Viveiros F, Marcos M, Faria C, Sousa F. Monitoring of fumarole discharge and $\mathrm{CO}_{2}$ soil degassing in the Azores: contribution to volcanic surveillance and public health risk assessment. Ann Geophys-Italy 2005;48:787-96.

Field RW, Steck DJ, Smith BJ, Christine P. The Iowa radon lung cancer study - phase I: residential radon gas exposure and lung cancer. Sci Total Environ 2001;272:67-72.

Garcia PV, Linhares D, Amaral AS, Rodrigues AS. Exposure of thermoelectric power-plant workers to volatile organic compounds from fuel oil: genotoxic and cytotoxic effects in buccal epithelial cells. Mutat Res Genet Toxicol Environ Mutagen 2012. http://dx.doi.org/10.1016/j.mrgentox.2012.05.008.

Hagmar L, Bonassi S, Strömberg U, Mikoczy Z, Lando C, Hansteen I. Cancer predictive value of cytogenetic markers used in occupational health surveillance programs: a report from an ongoing study by the European Study Group on Cytogenetic Biomarkers and Health. Mutat Res 1998;405:171-8.

Hallare AV, Gervasio MK, Gervasio PL, Acacio-Claro PJ. Monitoring genotoxicity among gasoline station attendants and traffic enforcers in the City of Manila using the micronucleus assay with exfoliated epithelial cells. Environ Monit Assess 2009;156:331-41.

Hansell AL, Horwell CJ, Oppenheimer C. The health hazards of volcanoes and geothermal areas. Occup Environ Med 2006:63:149-56.

Holland N, Bolognesi C, Kirsch-Volders M, Bonassi S, Zeiger E, Knasmueller S, et al. The micronucleus assay in human buccal cells as a tool for biomonitoring DNA damage: the HUMN project perspective on current status and knowledge gaps. Mutat Res 2008;659:93-108.

IARC. Man-made mineral fibers and radon. IARC Monogr Eval Carcinog Risks Hum 1988:43:33-171.

IARC. Occupational exposures to mists and vapours from strong inorganic acids, and other industrial chemicals. IARC Monogr Eval Carcinog Risks Hum 1992;54:41-130.

Iwasawa S, Kikuchi Y, Nishiwaki Y, Nakano M, Michikawa T, Tsuboi T, et al. Effects of $\mathrm{SO}_{2}$ on respiratory system of adult Miyakejima resident 2 years after returning to the island. J Occup Health 2009;51:38-47.

Jostes RF. Genetic, cytogenetic, and carcinogenic effects of radon: a review. Mutat Res 1996;340:125-39.

Knudsen LE, Hansen AM. Biomarkers of intermediate endpoints in environmental and occupational health. Int J Hyg Environ Health 2007;210:461-70.

Lee WJ, Teschke K, Kauppinen T, Andersen A, Jäppinen P, Szadkowska-Stanczyk I, et al. Mortality from lung cancer in workers exposed to sulfur dioxide in the pulp and paper industry. Environ Health Perspect 2002;110:991-5.

Mahimkar MB, Saman TA, Kannan S, Patilet T. Influence of genetic polymorphisms on frequency of micronucleated buccal epithelial cells in leukoplakia patients. Oral Oncol 2010;46:761-6.

Majer BJ, Laky B, Knasmüller S, Kassie F. Use of the micronucleus assay with exfoliated epithelial cells as a biomarker for monitoring individuals at elevated risk of genetic damage and in chemoprevention trials. Mutat Res 2001;489:147-72.

Maluf SW, Erdtmann B. Follow-up study of the genetic damage in lymphocytes of pharmacists and nurses handling antineoplastic drugs evaluated by cytokinesis-block micronuclei analysis and single cell gel electrophoresis assay. Mutat Res 2000;471 $21-7$
Martínez-Valenzuela C, Gómez-Arroyo S, Villalobos-Pietrini R, Waliszewski S, Calderón-Segura ME, Félix-Gastélum R, et al. Genotoxic biomonitoring of agricultural workers exposed to pesticides in the north of Sinaloa State, Mexico. Environ Int 2009;35:1155-9.

Martins RA, Gomes GAS, Aguiar Jr O, Ribeiro DA. Biomonitoring of oral epithelial cells in petrol station attendants: comparison between buccal mucosa and lateral border of the tongue. Environ Int 2009;35:1062-5.

Meng Z, Zhang B, Ruan A, Sang N, Zhang J. Micronuclei induced by sulfur dioxide inhalation in mouse bone-marrow cells in vivo. Inhal Toxicol 2002;14:303-9.

Meng Z, Qin G, Zhang B. DNA damage in mice treated with sulfur dioxide by inhalation. Environ Mol Mutagen 2005:46:150-5.

Pappas RS, Polzin GM, Zhang L, Watson CH, Paschal DC, Ashley DL. Cadmium, lead, and thallium in mainstream tobacco smoke particulate. Food Chem Toxicol 2006;44 714-23.

Pope III CA, Thun MJ, Namboodiri MM, Dockery DW, Evans JS, Speizer FE, et al. Particulate air pollution as a predictor of mortality in a prospective study of U.S. adults. Am J Respir Crit Care Med 1995;151:669-74.

Reddy GR, Devi BC, Chetty CS. Developmental lead neurotoxicity: alterations in brain cholinergic system. Neurotoxicology 2007:28:402-7.

Rozgaj R, Kašuba V, Brozović G, Jazbec A. Genotoxic effects of anaesthetics in operating theatre personnel evaluated by the comet assay and micronucleus test. Int J Hyg Environ Health 2009;212:11-7.

Salama SA, Serrana M, Au WW. Biomonitoring using accessible human cells for exposure and health risk assessment. Mutat Res 1999;436:99-112.

Saran R, Tiwari RK, Reddy PP, Ahuja YR. Risk assessment of oral cancer in patients with pre-cancerous states of the oral cavity using micronucleus test and challenge assay. Oral Oncol 2008;44:354-60.

Searle R. Tectonic pattern of the Azores spreading centre and triple junction. Earth Planet Sci Lett 1980;51:415-34.

Serviço Regional de Estatística dos Açores. Censos 2001: Principais Resultados Definitivos dos Censos 1991 e 2001. Angra do Heroísmo: SREA; 2003.

Sethi TK, El-Ghamry MN, Goetz H, Kloecker GH. Radon and lung cancer. Clin Adv Hematol Oncol 2012;10:157-64.

Silva C. Ferreira T, Viveiros F. Radon $\left({ }^{222} \mathrm{Rn}\right)$ soil gas measurements at Furnas Volcano (S. Miguel Island, Azores). Geophys Res Abstr 2007;9:08372.

Speit G, Witton-Davies T, Heepchantree W, Trenz K, Hoffman H. Investigations on the effect of cigarette smoking in the comet assay. Mutat Res 2003;542:33-42.

SPSS Inc. SPSS Base 15.0 for Windows User's Guide; 2006. Chicago, Illinois, USA.

Stich HF, San RHC, Rosin MP. Adaptation of the DNA-repair and micronucleus tests to human cell suspensions and exfoliated cells. Ann N Y Acad Sci 1983;407:93-105.

Thomas P, Holland N, Bolognesi C, Volders MK, Bonassi S, Zeiger E, et al. Buccal micronucleus cytome assay. Nat Protoc 2009;4:825-37.

Tolbert PE, Shy CM, Allen JW. Micronucleus and other nuclear anomalies in buccal smears: a field test in snuff users. Am J Epidemiol 1991;134:840-50.

Tolbert PE, Shy CM, Allen JW. Micronucleus and other nuclear anomalies in buccal smears: methods development. Mutat Res 1992;271:69-77.

Turner MC, Krewski D, Chen Y, Arden Pope III C, Susan Gapstur S, Thu MJ. Radon and lung cancer in the American Cancer Society Cohort. Cancer Epidemiol Biomarkers Prev 2011;20:438-48.

Viveiros F, Ferreira T, Cabral Vieira J, Silva C, Gaspar JL. Environmental influences on soil $\mathrm{CO}_{2}$ degassing at Furnas and Fogo volcanoes (São Miguel Island, Azores archipelago). J Volcanol Geotherm Res 2008;177:883-93.

Viveiros F, Ferreira T, Silva C, Gaspar JL. Meteorological factors controlling soil gases and indoor $\mathrm{CO}_{2}$ concentration: a permanent risk in degassing areas. Sci Total Environ 2009;407:1362-72.

Viveiros F, Cardellini C, Ferreira T, Caliro S, Chiodini G, Silva C. Soil CO2 emissions at Furnas volcano (São Miguel Island, Azores archipelago) - volcano monitoring perspectives, geomorphologic studies and land-use planning application. J Geophys Res 2010;115:B12208.

Waalkes MP. Cadmium carcinogenesis. Mutat Res 2003;533:107-20.

Yadav JS, Kaushik VS. Effect of sulphur dioxide on human chromosomes. Mutat Res 1996;359:25-9.

Zaichick VY, Tsyb AF, Vtyurin BM. Trace elements and thyroid cancer. Analyst 1995;120:817-21. 